\title{
VÁrkonyi Hildebrand ÉS a Polgári Iskolai Tanárképző FöISKola SzEgeden
}

\author{
FIZEL NATASA \\ Szegedi Tudományegyetem Juhász Gyula Pedagógusképző Kar, \\ Alkalmazott Pedagógiai Intézet
}

Jelen tanulmányom témája az Állami Polgári Iskolai Tanárképző Főiskola szegedi megalapítása és hazánk első Pedagógiai-Lélektani Intézetének létrejötte, valamint első vezetőjének, a katolikus Várkonyi Hildebrandnak a munkássága. Intézetében a neveléstudomány és a pszichológia egymástól elválaszthatatlan egységként müködött. Munkámban bemutatom Szegedre kerülésének különleges körülményeit, amelyek kiváltó oka elsősorban az volt, hogy a protestáns jellegű kolozsvári egyetem 1921-től kezdődően Szegeden, egy püspöki székhelyen került elhelyezésre. Klebelsberg a Bölcsészkar alacsony látogatottságát növelni kívánta, a katolikus lobbi nyomására az egyetem protestáns jellegét pedig csökkenteni. Ebbe a folyamatba illeszkedik a budapesti székhelyű polgári iskolai tanár-, illetve tanárnőképző főiskolák összevonása és Szegedre helyezése, valamint ezzel párhuzamosan a felekezeti tanárképzők megszüntetése. Várkonyi pedagógia-lélektana a főiskolások egyetemre való áthallgatása révén beépült a polgári iskolai tanárok kultúrájába.

Kulcsszavak: felsőoktatás-történet, pedagógia- és pszichológiatörténet, pedagógusképzés

My following study is about the establisment of the State Civic School Teacher's Training College in Szeged. It also contains information about the establishment of our country's first Educational-Psychological Instute, and of it's first (catholic) headmaster's, Hildebrand Várkonyi's work. The University of Szeged was put together of protestant teachers from the university in Kolozsvár in 1921. The Religious and Educational Board helped increase the attendance of the Faculty of Liberal Arts, but also decreased the protestant nature of it. The Religious and Educational Board also achieved this by moving the state, and catholic teacher's training college from Budapest to Szeged and by duplicating the departments of the remaining protestant Faculties of Liberal Arts. Várkonyi's pedagogy and psychology got built into the culture of civic schools.

Keywords history of higher education, history of psychology, teacher's training

Levelező szerző: Fizel Natasa, SZTE JGYPK Alkalmazott Pedagógiai Intézet,

6725 Szeged, Hattyas sor 10. E-mail: fizel.natasa@szte.hu 
$\mathrm{V}$ árkonyi Hildebrand Dezső egyetemi tanár tudományos, oktatói és tudományos-közéleti munkássága, valamint az általa vezetett, hazánkban elsőként létrehozott Pedagógiai-Lélektani Intézet históriája és kísérleti iskolájának, a Kerti Iskolának a története már számos szerző által feldolgozásra, bemutatásra került. 1988-ban, születésének 100. évfordulóján tanítványai, pályatársai ${ }^{1}$ egy emlékkötetben emlékeztek meg a professzor munkásságáról, személyiségéről, oktatói nagyságáról (Zakar 1988). 2009-ben a Várkonyi-féle intézet jogutódja, a Szegedi Tudományegyetem Bölcsészettudományi Kar Pszichológiai Intézete az intézet fennállásának 80. évfordulójára jelentetett meg egy, a lélektan történetével foglalkozó kötetet (Szokolszky 2009).

A Várkonyi által alapított, saját korában rendkívül újszerünek számító újszegedi Kerti Iskola története az 1990-es évek végén került a tudományos érdeklődés középpontjába elsősorban Pukánszky Béla és Németh András kutatásainak jóvoltából (NémethPukánszky 1997, 1999; Pukánszky 2002). A kutatás a 2010-es években a Pukánszky Béla által elérhetővé tett forrásgyüjteménynek köszönhetően folytatódott. Újabb és újabb publikációk láttak napvilágot a Kerti Iskola müködéséről (Fizel 2012), módszertani palettájáról (Kiss 2016), vezetőjének, Dolch Erzsébetnek az életútjáról (Fizel 2013), valamint Várkonyi Hildebrandnak a korabeli pedagógiai gyakorlatra kifejtett hatásáról (Szabó 2016).

A főiskola históriájának témájában e tanulmány szerzője mellett a közelmúltban újabb adalékokkal szolgáltak a Nóbik Attila (2010), T. Molnár Gizella (2010), valamint Vajda Tamás (2010) tollából született tanulmányok. Várkonyi Hildebrand Szegedre kerülésének történetét nagyrészt primer források alapján dolgoztam fel, egyebek mellett a szegedi egyetem Bölcsészettudományi Kar tanácsüléseinek jegyzőkönyveit, Mészöly Gedeon dékánnak és Dézsi Lajos rektornak a Klebelsberg Kuno vallás- és közoktatásügyi miniszterrel folyó levelezését használtam fel.

\section{Várkonyi Hildebrand Szegedre kerülésének körülményei}

A kolozsvári Ferenc József Tudományegyetem fejlődése töretlen volt az első világháború kitöréséig. Történetében sorsdöntő fordulatot hozott, hogy a román hadsereg 1918. december 24-én bevonult Kolozsvárra (Benda 1982: 846). 1919. május 12-én a román katonaság elfoglalta az egyetemet is, majd a rektori hivatal élére a román tanszék professzorát nevezték ki (Makk-Marjanucz 2011: 10). Az egyetemi tanárok a város megszállása után nem tették le a román állampolgárság elnyeréséhez szükséges esküt, így kiutasították őket a városból.

$\mathrm{A} z$ elveszett Kolozsvári egyetem szerepét, oktatói karát és hallgatóinak töredékét Szegeden, a tanítóképzés, a Jogakadémia, a Városi Zenede elődintézményeire is építkezve a Szegeden új életet kezdő Ferencz József Tudományegyetem vette át. Az első tanévet 1921. október 9-én nyitották meg, ezzel megkezdődött Szegeden a tényleges egyetemi oktatás.

A kolozsvári, döntően protestáns hátterü egyetem egy többségében katolikus városban, püspöki székhelyen, Szegeden kapott helyet, ami megváltoztatta a közpolitikai életben ekkor nagyjelentőségű felekezeti erőviszonyokat.

Rókusfalvy Pál, Duró Lajos, Veckó József, Baróti Dezső, Zentai Károly, Veszprémi László, Kiss György, Büky Béla és Sellei Zoltán. 
1926. október 20-án a Bölcsészkar évi II. rendes ülésén Bartók György dékán bejelentette, hogy Klebelsberg Kuno, vallás- és közoktatásügyi miniszter az egyetemen új tanszékek felállítását óhajtja. A Kar egy pedagógiai-lélektani, egy müvészettörténeti és egy etnográfiai tanszék felállítását tartotta a lesürgetőbbnek és a legfontosabbnak. ${ }^{2}$

Ez a kérvény segítette Klebelsberget abban, hogy keresztülvigye korábbi terveit, és a protestáns professzorok mellett katolikus intézetvezetők is helyet kapjanak azokon a tudományterületeken, ahol a felsőoktatás-átalakítási tervei következtében szükségesnek vélte. Megelőzendő, hogy a nagy tudású, munkájukat jól végző professzorokat sérelem érje, a miniszter a tanszékek párhuzamosításával akarta az ügyet megoldani. 1928. június 29-én, a Bölcsészkaron rendkívüli ülésen tárgyalták a párhuzamos tanszékek kérdését. Az elnök, Horger Antal dékán kérte a Kar állásfoglalását arra vonatkozólag, hogy második filozófiai vagy második pedagógiai tanszék felállítását kérjék-e a miniszter úrtól. Imre Sándor (aki 1925 óta vezette a Pedagógiai Intézetet) és Bartók György nem javasolták a párhuzamos tanszékek felállítását, inkább - ismét - egy pedagógiai-pszichológiai tanszék felállítását kérték, amit a Kar el is fogadott. ${ }^{3} \mathrm{Az}$ 51.5871928. IV. számú miniszteri rendelet alapján úgy tűnt, hogy a vita lezárásra került, és a miniszter az alábbi döntést hozta: „a szegedi m. kir. Ferenc József Tudományegyetemen négy új tanszék és pedig ethnográfia, a II. filozófia és a II. magyar irodalomtörténet számára egy-egy nyilvános rendes és a II-ik pedagógia számára pedig egy nyilvános rendkívüli tanszék szerveztessék."

A rendelet megjelenése ellenére a Bölcsészkaron továbbra is nagy volt az ellenállás az új tanszékek megalakításával kapcsolatban. Az okok között szerepelt a Nemzeti Újság 1928. dec. 16-i vezércikke is, amely szerint Klebelsberg az alábbi nyilatkozatot tette: „A szegedi egyetemen kész vagyok azok mellett, amelyeket nem katolikus férfiak töltenek be, parallel tanszékeket létesíteni s azokra katolikus tanárokat kinevezni, hogy a tartományi főnöknőknek aggodalmaik ne legyenek. Itt neveltessék női szerzetesrendjeink az általuk fenntartott polgári iskolák, középiskolák és tanítóképzők tanári karát."

Bár a hivatalos dokumentumokban (pl. az új tanszékek élére kiírt pályázatokban) nem szerepelt a felekezeti hovatartozás feltételként, az újságcikkben a miniszter világossá tette ezt az óhaját. Informális csatornákon keresztül Klebelsberg fülébe jutott, hogy a szegedi egyetemen feliratot készítenek intézkedése ellen, így sértett hangvételü levélben fordult az egyetem rektorához, aki ekkoriban (1928-29-ben) éppen az egyik érintett, az Irodalomtörténeti Tanszék vezetője, Dézsi Lajos volt. A miniszter levelében kitért arra, hogy a VKM felügyelete alatt álló Takarékossági Bizottság a szegedi egyetem teljes eltörlését javasolta, és e szándék mellett szólt a hallgatók száma, ahogy az egyik bizottsági tag gúnyosan meg is jegyezte, hogy „a bölcsészeti karoknak több tanár-

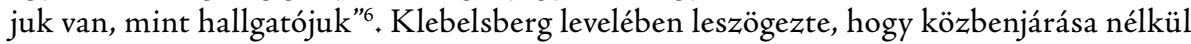
a szegedi bölcsészkar az ő miniszterségét aligha élte volna túl: „a bölcsészeti karok benépesítésének érdeke volt az egyik oka annak is, hogy a Paedagogiumot és az Erzsébet

Jegyzökönyv, Bölcsészettudományi Kar II. rendkivüli ülés, 1926. okt. 20. MNL CSML VIII. 167. bk. 87.

3 Jegyzökönyv, Bölcsészettudományi Kar V. rendkivüli ülés, 1928. június 29. MNL CSML VIII. 651. bk. $1927 / 28$.

4 M. Kir. Vallás-és Közoktatásügyi Minisztérium 51.587-1928. IV. sz. rendelet

5 Nemzeti Újság, 1928. december 16. 1.

6 Klebelsberg Kuno miniszter levele Dézsi Lajos rektornak. Budapest. 1929. január 4. MOL K636-1929-30410-05 
Nőiskola főiskolai tagozatát Szegedre levittem”, és így került az apácák polgári iskolai tanárképzése is Szegedre. „Indokom ismét pedagógiai volt, tudniillik a női szerzetesrendek iskolái nívójának emelése, amire azért is súlyt kell helyeznem, mert a magyar leányok igen számottevő része éppen ezekben az iskolákban nyeri egyedüli nevelését. De emellett megint szemem előtt lebegett a szegedi bölcsészeti karoknak további erőteljes benépesítése, mert a karok felvirágoztatása csak akkor lehetséges, ha igazán nagyszámú hallgatóságuk van." ${ }^{8}$ Kitért arra is, hogy a Nemzeti Újságban megjelent cikk ugyan az ő véleményeként adta közre a világnézeti tanszékek létrehozásának tervét, valójában ez a püspökök állásfoglalása volt. Klebelsberg nem vonta vissza a párhuzamos tanszékek felállításáról korábban kiadott rendeletét, így végül a tanszékek betöltésére szolgáló adminisztrációs folyamat a Bölcsészkaron mégis beindult.

A folyamat azonban egyáltalán nem volt zökkenőmentes, és a Kari Tanács továbbra is erősen megosztott volt a kérdésben. A két ellentétes véleményt képviselő tábor vezetői a katolikus Huszti József és a református Imre Sándor voltak, akiknek a Bölcsészkar 1929. április 25-i VIII. rendes ülésén lezajlott szócsatája élesen rávilágít arra a légkörre, amelyben a párhuzamos tanszékek felállítása ügyének tárgyalása zajlott.

Huszti József a II. pedagógiai tanszék bizottságának előadója a tanszék betöltésére pályázat kiírását indítványozta (felmerült ugyanis, hogy meghívással töltik be a tanszéket). A szavazás elrendelése előtt dr. Imre Sándor a Pedagógia Tanszék vezetője szót kért, és leszögezte, hogy a párhuzamos tanszékek felállításának előkészítését végző bizottságok létrehozásakor ugyan még ő maga is szavazott, de azt remélte, hogy a Kar jelzéseire reagálva a miniszter visszavonja a rendelkezését. Mivel azonban ez nem történt meg, a párhuzamos tanszékek ügyének további tárgyalásában nem kíván részt venni. Így fogalmazott: „ezek szervezése köztudomás szerint nem tudományos célból történik s ha a Kar ezt számba nem véve tesz javaslatot, azzal egyszerüen a valóságot hagyja figyelmen kívül, ebben pedig én nem kívánok részes lenni; annál kevésbé, mert a három tanszék kifejezetten a szakok mai rendes tanárainak személye miatt, ezek ellenében szerveztetik s mint ezek egyike, önként érthetően nem müködhetek közre azoknak a tanszékeknek betöltésében, amelyek létesítése egyebek között az én tudományos tárgyiasságomnak nyílt kétségbevonását is jelenti. [...] Az ily módon mélyen érintett tanárok mellett a bizottságnak és a Karnak egyetlen szava sem volt; az ülésről nem távozok el, de a bizottsági jelentések elfogadása tárgyában üres lappal szavazok." ${ }^{10}$

Imre tehát a paralell tanszékek felállítását - mint az egyik érintett tanszék vezetője - személyes támadásnak vette, és elutasította a feltételezést, hogy vallási meggyőződése bármilyen módon nyomot hagyna az általa tartott előadások tartalmán. Ebből következően utasította el tehát Klebelsberg érveit is, amelyekkel az előadások világnézeti alapon történő választhatóságát sürgette.

Huszti József Imre Sándor sértődött szavaira az alábbiakkal reagált: „a Kar az előző két tanév folyamán a Miniszter Urtól ismételten egyhangúlag kérte, illetőleg egyhangú örömmel fogadta többek között a II. philosophiai, pedagógiai, és magyar irodalom-

\footnotetext{
7 Uo.

8 Uo.

9 Jegyzőkönyv. Bölcsészettudományi Kar VIII. rendes ülés. 1929. április 25. MNL CSML 555. bksz. $1928 / 1929$.

10 Uo.
} 
történeti tanszékek szervezését [...], az előző tanévek ismételt tárgyalásai alkalmával a vonatkozó jegyzőkönyvek tanúsága szerint még a gondolata sem vetődött fel annak, mintha a szóbanforgó tanszékek az illető tudományszakok mai rendes tanárainak személye miatt, mintegy ezek ellenében szerveztetnének." 11

Huszti tehát a maga részéről elutasította a feltételezést is, hogy a párhuzamos tanszékeknek szervezése bármelyik kolléga vallási elfogulatlanságának, tudományosságának nyílt kétségbevonását jelentené, és érthetetlen reakcióként, sértődött vagdalkozásként állította be Imre véleményét. Imre Sándor azonban pontosította a Huszti-féle csúsztatást, amikor hangsúlyozta, hogy a Kar II. pedagógiai tanszéket sohasem kért, mindig pedagógiai-lélektani tanszék felállítására tett javaslatot, s a Kar ezt fogadta el egyhangúan. „Mikor azután az egyetem akkori rektorától azt hallom, hogy ez a javaslat az egyetemnek kárt okozhat, mert nem egyezik meg a Miniszter Úr kívánságával, a dékánhoz írt levélben javaslatomtól elállok, de más (személy) javaslatot nem tett, a Kar más javaslatot az ő tudtával nem is tárgyalt, s az ügy 1928 júniusáig szünetelt; ekkor a dékán ismét szóbeli utasításra hivatkozva az évzáró ülés után már elszéledt tanároktól írásban azt kérdezte, vajon mit kíván a Kar inkább: II. filozófiai vagy II. pedagógiai tanszéket. Erre a filozófia tanárai (által) közösen aláírt véleményben újból pedagógiai lélektani tanszéket mond indokoltnak, a párhuzamos tanszéknek hevesen ellene szólnak, s a távollétükben tartott rendkívüli ülésen a Kar szintén pedagógiai-lélektani tanszék mellett nyilatkozott, bár hozzá tette, hogy ha ez nem lehetséges, arra az esetre filozófiai tanszéket kért."12

Imre tehát meglehetősen nyíltan fogalmazva utalt arra, hogy a "választhatóság” a tanszékek esetében pusztán elviekben állt fenn, hiszen a miniszter már korábban eldöntötte a paralell tanszékek sorsát, sőt a rektor tudomására hozta az erről való döntését, akit arra sarkalt, hogy érje el, hogy a Bölcsészkar is az ő elképzelése alapján kérje a tanszékeket. Imre hangsúlyozta, hogy az csak a látszat, hogy a kari tanácsnak bármibe beleszólása lenne ezekkel a tanszékekkel kapcsolatban, azért emelte fel a szavát, mert ezt az eljárást nehezményezte. Végül Huszti a vita lezárásaként elismerte, hogy az előző tárgyalások folyamán mindig lélektani irányú pedagógiai (pedagógiai-lélektani) tanszékről volt szó, és a Kar egy ilyennek felállítására tett javaslatot, ugyanakkor felhívta a figyelmet arra a kiskapura, hogy „a tanszékek által képviselt tudományszakok pontosabb tartalmát egyébként sem a tanszékek elnevezése, hanem inkább a kiszemelt professzorok tudományos egyénisége determinálja”. Mindegy tehát, hogy mi lesz a tanszék neve, az a lényeg, hogy ki fogja azt tartalommal megtölteni. A maratonira nyúló tanácskozás végén a Kar a II. pedagógia tanszék betöltésére szóló pályázatot titkos szavazással 6 igen, 1 nem és 5 üres lap ellenében elfogadta.

A II. pedagógia tanszékre kiírt pályázat szövegét ${ }^{13}$ megvizsgálva szembetűnő, hogy abban a lélektan vagy a pszichológia kifejezés nem szerepel.

$\mathrm{A} z$ újonnan szervezett három tanszékre összesen kilenc pályázat érkezett. A II. filozófia tanszékre a jezsuita dr. Mester János, a bencés dr. Bognár Cecil, a katolikus dr. Somogyi József és dr. Boda István, a II. pedagógia tanszékre a bencés dr. Várkonyi

\footnotetext{
11 Uo.

12 Uo.

13 Pályázat. MNL CSML ad. 581. bk. 1928/1929.
} 
Hildebrand, az említett dr. Mester János és dr. Berenkay Lajos, a II. magyar irodalomtörténeti tanszékre dr. Sík Sándor és dr. Földessy Gyula adta be a pályázatát. ${ }^{14}$

Imre Sándor belátta, hogy a tanszékek létrehozása elleni harcot elvesztette, de nem adta fel, hogy az ügyet a nyilvánosság elé vihesse. A Bölcsészkar 1929. október 29-i kari tanácsi ülésén döntött a pályázatokról. ${ }^{15} \mathrm{~A} z$ áprilisi üléshez hasonlóan a szavazás lebonyolítása előtt Imre szólásra emelkedett: „[...] kérnem kell a tekintetes Kar döntését azért, mert ismeretlen forrásból az a híresztelés terjedt el az egyetem tanárai között, és Egyetemünkön kívül is, hogy akik az u. n. világi tanszékeket karunkon ellenzik, azok ebből az ügyből vallási, felekezeti kérdést csináltak. Ez a híresztelés a valósággal tökéletesen ellentétes. Ezért szükséges megállapítani, hogy 1. itt egyetlen szó sem esett felekezeti sérelemről, hanem igenis egyetemi eszmény sérelméről, arról, hogy egyetemi tanszéket ne lehessen felekezeti, vagy egyéb a tudományos érdeken kívül eső érdekből szervezni és betölteni. 2. nem arról van szó, hogy bármely üres, vagy új tanszék betöltésére legméltóbbnak talált szakember milyen vallású, hanem arról, hogy a legméltóbbnak a kiválasztásában ne legyen sem döntő sem irányadó a vallási hovatartozás és ne legyen kikötve, hogy egyik egyetemen ilyen, a másikon amolyan vallású lehet bármelyik világi tanszék tanára."

Imre azonban nem ért célt a kérésével, indítványa lekerült a napirendről, bár jól látható a tanács megosztottsága, hiszen 7 igen, 6 nem és 1 üres lap volt a beadott szavazatok aránya. A II. pedagógia tanszék élére a kari bizottság első helyen Várkonyi Hildebrandot, második helyen Mester Jánost jelölte. Várkonyi 13 szavazatból 8 igen, 1 nem és 4 üres lapot kapott, míg Mester 7 igen, 2 nem és 4 üres lapot.

Imre azonban láthatóan készült erre a forgatókönyvre is, hiszen a szavazás után azonnal szót kért, és írásbeli indítványt terjesztett a Kar elé, amelyben az események történelmi fontosságát hangsúlyozta: „1, az 51.587/1928. sz. miniszteri rendelettel szervezett tanszékek mind Karunk, mind általában a magyar tudományos élet jövőjére messzire kiható jelentőségűek: egyik tanszék az egyetemeinken eddig nem képviselt tudományszaknak nyitotta meg az egyetemet, a másik három tanszék ügyét pedig széleskörủ érdeklődés kíséri, egy év óta nagyon ellentétes nézetek ütköznek össze miatta, s e tanszékek betöltése az illető tudományszakok jövőjére is nagy hatású lesz. Ezért történelmi fontosságúak mindazok az írások, amelyek a négy tanszék ügyében keletkeztek. Javaslom, határozza el a tek. Kar mindezek, tehát a szervező miniszteri leirat, a Kar elé terjesztett indítványok, bizottsági jelentések és kari határozatok kinyomtatását. Ha erre a tek. Kar a hivatalos titok szempontjából nem tartja magát jogosultnak, kérjen felmentést a titoktartás alól. 2, Ha a tek. Kar ezt a javaslatomat nem fogadná el, akkor kérem, méltóztassék engedélyt adni nekem arra, hogy a négy uj tanszék ügyében az üléseken előadott indítványaimat és felszólalásaimat szükség esetén a nyilvánosság előtt felhasználhassam. Erre a kérésre az indít, hogy mivel egyedül, vagy föképpen én szólaltam fel a Kar ülésein a tanszékek ügyében, elsősorban engem állítnak egészen téves világításba azok a híresztelések, amelyek az u.n. világnézeti tanszékek ellenzőit felekezetieskedéssel vádolják. Mivel felekezeti szempontból soha, még felekezeti iskolában való szolgálatom alatt sem tettem semmit és erős meggyőződésem szerint ebben a kérdésben is tisztán az egyetem szempontját igyekeztem érvényesíteni; ezt a gyanusítást

14 Jegyzökönyv. Bölcsészettudományi Kar, 1929. június 13. MNL CSML 689. bk. 1928/29.

15 Jegyzőkönyv. Bölcsészettudományi Kar II. rendes ülés. 1929. október 28. MNL CSML 174. bk. 1929/30. 
magamtól határozottan elhárítom, de előfordulhat, hogy ellene magamat védenem kell. E végből kérek a tek. Kartól felhatalmazást, a jegyzőkönyvben foglalt nyilatkozataim (indítványaim és felszólalásaim) esetleges felhasználására."

A Kari Tanács nem akart állást foglalni az ügyben, így az Egyetemi Tanács elé terjesztette, amely 1929. december 11 -i ülésén a kérést elutasította. ${ }^{16}$

1929 decemberében a pedagógiai-lélektani tanszék élére Dr. Várkonyi Hildebrandot nevezte ki Klebelsberg Kuno. ${ }^{17}$ A II. irodalomtörténet tanszék vezetője - Dézsi Lajos halálát követően - 1930-tól a piarista Sík Sándor, a II. filozófia tanszék professzora pedig Mester János lett (Pukánszky 1999: 219).

A párhuzamos tanszékek nem értek meg hosszú időt. Dézsi Lajos 1932-es halálával Sík Sándor piarista tanár egyesítette és vitte tovább a két magyar irodalomtörténeti tanszéket. Az új Pedagógiai-Lélektani Intézet 1934-ben, Imre Sándor Budapestre távozása után egyesült a korábbi Pedagógiai Intézettel, majd Várkonyi Hildebrand 1940-es Kolozsvárra való költözését követően megszűnt a II. filozófiai intézet, és a Neveléstudományi és Lélektani Intézet vezetését Mester János vette át.

\section{Várkonyi Hildebrand, a professzor}

Várkonyi tehát 1929-ben kezdte el a munkát az egyetemen. Ahogy Zakar András a Várkonyi (Hildebrand) Dezső emlékkötet Előszavában írja:

„Életének legtermékenyebb időszaka következett. Nyilvános rendes egyetemi tanári működése során az oktató-nevelő munkája, tudományos kutatásai és szakmai közéleti tevékenysége alapján az egyetem egyik legismertebb professzora lett." (Zakar 1988: 3.)

A bizonyíték arra, hogy szükség volt - még ha egy szokatlan történelmi fordulat, egy egyetem elköltöztetése okán is - a Várkonyi-féle intézet létrehozására nemcsak felekezeti, hanem szakmai okokból is (ahogy ezt maga Imre Sándor is szorgalmazta már 1926-tól kezdődően), jól kiviláglik, ha megnézzük a két intézet, azaz a korábbi Pedagógiai Intézet (1929-től I. Pedagógiai Intézet), valamint a Várkonyi féle II. PedagógiaiLélektani Intézet (1934-től Pedagógia Intézet) által kínált kurzusokat (Melléklet). Ezek az órák jelentették a pedagógiai, pszichológiai alapokat a harmincas években a szegedi egyetemről kikerülő középiskolai tanárság számára, így jelentőségük nemcsak a tanárok konkrét tudásának megbecsüléséhez segít hozzá minket, hanem lehetőséget ad arra is, hogy a pedagógiai attitüdjük felvázolásához is közelebb jussunk. Az alábbiakban néhány példát emeltem ki a két intézet által hirdetett kurzusokból. ${ }^{18}$

A megfelelő mértékű rálátást elősegítendő, a párhuzamos tanszékek felállítása előtti négy tanévet is górcső alá vettem (1926-1930), amikor megvizsgáltam azokat a kurzusokat, amelyeket a Pedagógiai Intézetben 1930 előtt hallgathattak a bölcsészkar hallgatói. A kurzusok sorát áttekintve egyértelmüen látszik, hogy Imre Sándor a hagyományos, a tanárképzésben több évtizedes múltra visszatekintő tantárgyakat preferálta. A neveléstörténet oktatása mellett (Neveléstörténet I-II.; Magyar pedagógusok; A nevelői gondolkodás fejlődése) a neveléstudomány általános megismerése (A neveléstudo-

16 Jegyzökönyv. Ferencz József Tudományegyetem Tanácsa IV. rendes ülés. 1929. december 11. MNL CSML 677-1929/30.

17 Várkonyi Hildebrand kinevezése. 1929. december 27. MNL OL 410-11-2078/1929.

18 A kurzusok listáját az alábbi tanrendek segítségével készítettem el: A M. K. Ferencz József-Tudományegyetem Tanrendje az 1926/27-1939/40. tanév első és második félévére, Szeged 1926-1939. 
mány fejlődése), az oktatási rendszer szervezetének kérdései (A köznevelés szervezete), valamint az oktatás- és a neveléselmélet (Oktatástan; A neveléselmélet alapvető kérdései) kapták a legnagyobb szerepet, de néhány kurzus erejéig már a nevelés pszichológiai megközelítése is helyet kapott az órái között (A nevelés lélektani kérdései; A serdülés kora; Az iskolai nevelő lélektana).

Azonban 1930-tól 1932-ig, azaz a két intézet párhuzamos működése során világosan szétvált a pedagógiai és a lélektani kurzusok hirdetése. Az Imre Sándor által vezetett I. Pedagógiai Intézet a neveléstudományi (nevelésszociológiai, iskolai egyészségtani) kurzusokat (Az értelmi nevelés; A magyar közoktatásügy szervezete; A nevelés szociológiája; $\mathrm{A} z$ iskola egészségügye), míg a II. Pedagógiai-Lélektani Intézet értelemszerűen a pedagógiai-lélektani kurzusokat hirdette (Karakterológiai vizsgálatok; Bevezetés az alkalmazott lélektanba; Pedagógiai-lélektani gyakorlatok; A gyermekkor lélektana). Jól látszik a kurzusok címét áttekintve, hogy a Várkonyi-kurzusok mennyire új, mennyire modern megközelítésben fordultak a lélektan tanítása felé az alkalmazott pedagógia és pszichológia kapcsolódási pontjainak a középpontba állításával, mintegy friss szellőt hozva az intézet falai közé. Ahogyan Szántó Károly, a Várkonyi-tanítvány írta róla 1984-ben:

„Várkonyi Hildebrand Dezső a polgári liberális haladó pedagógia egyik magas színvonalú képviselője, ugyanakkor az európai élvonal szellemi közvetítője volt hazánkban. Kora nemzetközi színvonalán állt mindabban, amit a neveléslélektani kutatások, a kísérleti pedagógia és pszichológia, a gyermektanulmány és a legjobb reformpedagógiai törekvések jelentettek." (Szántó 1984: 1232.)

Imre Sándor 1934-ben történt távozása után - amiben szerepe lehetett a párhuzamos tanszékek felállítása körüli vitának is - a két intézet egyesült. Várkonyi részben átvette a pedagógiai előadásokat (Neveléstörténet I-II; Bevezetés a neveléstudományba), de oktatói munkájának és az intézet müködésének fókuszában továbbra is a pedagógiai lélektan állt (Neveléslélektan; Gyermeklélektan; Az ifúkor lélektana).

Várkonyi kurzusai nemcsak a középiskolai tanárnak készülő hallgatók számára voltak elérhetőek, felvehették azokat az Állami Polgári Iskolai Tanárképző Főiskola hallgatói is. Mint tanulmányom korábbi részében említettem, 1928-ban került Szegedre a korábban budapesti székhelyű Paedagogium és Erzsébet Nőiskola összevonásával és a felekezeti képzők megszüntetésével az országban monopol helyzetűvé vált Állami Polgári Iskolai Tanárképző Főiskola. Az intézmény Szegedre kerülése - és az ott tanuló nagy számú apáca hallgató - indította be a párhuzamos tanszékek létrehozásának folyamatát is, hiszen Klebelsberg az áthallgatásra kötelezett főiskolásokkal kívánta a szegedi egyetem hallgatói létszámát megnövelni. Kezdetben a föiskolásoknak félévenként két kurzust kellett a szakjuknak megfelelően vagy a bölcsészettudományi, vagy a temészettudományi karon felvenniük, pedagógiai, pszichológiai, illetve filozófiai tárgyakat csak külön engedéllyel hallgathattak. 1933-tól kezdődően azonban megnyíltak a kapuk, és a hallgatók bármilyen kurzust felvehettek az egyetemen. A hallgatói 
anyakönyvekből kinyert ${ }^{19}$ adatok tanúsága szerint évről évre több hallgató élt azzal a lehetőséggel, hogy pedagógiai, pszichológiai, vagy filozófiai kurzusokat hallgasson az egyetemen a szaktárgyi kurzusok helyett. Míg az 1933-34-es tanév első félévében mindössze 14 alkalommal vettek fel ilyen témájú kurzust a hallgatók, addig ez a szám 1941-re már 132-re emelkedett, és 1943-ra is csak 72-re csökkent. A vizsgált időszakban 661 alkalommal vettek fel 48-féle nem szaktárgyi, azaz pedagógiai, pszichológiai, filozófiai témájú kurzusból órát a főiskolások a szaktárgyukhoz kapcsolódó kurzusok helyett.

A főiskolások Várkonyinak nemcsak a lélektani, hanem a pedagógiai előadásait is szívesen látogatták. Legendásan modern, érdekfeszítő előadásairól korábbi tanítványa, Baróti Dezső (1988: 181) így írt:

„A szenzáció erejével hatottak a »Várkonyi-órák« és a szemináriumok. Már csak azért is, mert ezek során sokkal behatóbban ismertette a tárgyalt kérdések irodalmát, mint a publikációiban, ahol elegendő lehetett, ha szűkszavúan szólt róla. Így azután nem csak a pedagógiai lélektan új irányzatait (Claparéde, Ferriére, Piaget etc.) méltatta, a modern pszichológia szinte valamennyi jelentős képviselőjével megismerkedhettünk nála, többek között Pavlovval, Freuddal, Junggal, Adlerrel, hogy csak azoknak a nevét említsem most, akikről akkoriban nemcsak hazánkban, más országokban sem sokat beszéltek az egyetemi katedrákról. Aligha túlzok tehát, amikor azt állítom, hogy azt a korszerű lélektani műveltséget, amelynek így vagy úgy későbbi pályánkon is nagy hasznát vettük, nálunk akkoriban csak a szegedi egyetemen lehetett megszerezni."

A polgári iskolai tanárnak készülő hallgatók számára egyedülálló lehetőséget jelentett, hogy bejárhattak Várkonyi óráira. Az 1936-ban megnyílt Kerti Iskolájának a vezetője, Dolch Erzsébet is főiskolai hallgatóként került Várkonyi közelébe, majd 1940-ben tanítványaként szerzett doktori címet.

\section{A polgári iskolai tanárság ethosza}

A polgári iskolai tanárság identitása a népiskolai tanítóságtól, a középiskolai tanárságtól elhatárolódva építkezett. A két háború közötti identitásuk kialakulásában, illetve megerősödésesben jelentős szerepet játszott a monopolhelyzetben lévő szegedi Polgári Iskolai Tanárképző Főiskola intézménye és benne Várkonyi Hildebrand tevékenysége.

1938-ban és 1940-ben látott napvilágot klasszikus kézikönyvnek számító könyve, a kétkötetes Gyermeklélektan, majd 1937-ben a Bevezetés a neveléslélektanba címü müve, továbbá az Országos Közoktatási Tanács által 1943-ban kiadott, a szerző szándékai szerint a „Lelki egészségtan” címet viselő, de végül a Lelki élet zavarai címmel megjelent könyve is.

1934 és 1944 között írta a Cselekvés Iskolája címü folyóiratban megjelent 37 cikkét is, amelyek részben előtanulmányok is voltak neveléslélektanához, részben alkalmazó kifejezései fejlődéslélektanának és cselekvéslélektanának. Ezek a munkák kifejezetten

19 Rendes Hallgatók Anyakönyve (RHA). Földrajz-természettan-vegytani szakcsoport 1928-1942. SZTE Egyetemi Levéltár (EL) 125. kötet; RHA Magyar-német nyelvi szakcsoport 1928-1942. SZTE EL 124. k.; RHA Magyar nyelvi-történelmi szakcsoport 1928-1942. SZTE EL 122. k.; RHA Mennyiségtan-természettanvegytani szakcsoport 1928-1942. SZTE EL 123. k.; RHA Földrajz-természettan-vegytani szakcsoport 19281942. SZTE EL 125. k.; RHA Magyar-német nyelvi szakcsoport 1928-1942. SZTE EL 124. k.; RHA Magyar nyelvi-történelmi szakcsoport 1928-1942. SZTE EL 122. k.; RHA Mennyiségtan-természettan-vegytani szakcsoport 1928-1942. SZTE EL 123. k. 
a gyakorló pedagógusok részére szolgáló, a mindennapi munkájuk során alkalmazható útmutatásul íródtak. Cikkeinek olvasása során magától értetődő, hogy a pedagógiát az alkalmazott pedagógiai pszichológia részének tekintette. Csak később változott meg ez a nézete, amikor 1946-ban a Magyar Pedagógiai Társaság ünnepi ülésén tartott elöadásában már önállónak tartott neveléstudományról beszélt, melynek emberismereti, embereszméleti alapot a pszichológia, pontosabban a pszichológiai antropológia ad (Rókusfalvy 1988: 156-158).

A Cselekvés Iskolája címü didaktikai, pedagógiai, módszertani folyóirat 1933 és 1944 között jelent meg. Szerkesztője dr. Kratofil Dezső, a szegedi Állami Polgári Iskolai Tanárképző Főiskola gyakorló iskolájának igazgatója, kiadója a gyakorló polgári iskola tanári testülete volt. A szerkesztőség a Boldogasszony sugárút 8. szám alatt, tehát a Gyakorló Iskola épületében kapott helyet. A folyóiratba a szegedi Polgári Iskolai Tanárképző Főiskola és a magyar királyi Ferencz József Tudományegyetem tanárai, illetve a modern pedagógiai gondolkodás képviselői írtak, például Dr. Várkonyi Hildebrand Dezső, Baróti Dezső vagy az Új Iskola vezetője, Dr. Domokos Lászlóné. A folyóirat 12 évfolyamban, évente öt kettős számban jelent meg. Hatását az mutatja, hogy szinte minden polgári iskolában, középiskolában előfizettek rá (Pitrik 1999: 409; Veszprémi 1988: 195).

Veszprémi László így fogalmazta meg a Cselekvés Iskolája létrejöttének okát: „A két világháború közötti neveléstudomány jelentős, sok tekintetben hézagpótló kezdeményezése volt ez a folyóirat, és maga köré gyüjtötte mindazokat, akik a hagyományos oktató iskolával szemben a tanulók aktivitását, tevékeny, cselekvő erőinek felszabadítását, az élet követelményeinek figyelembevételét, a gyakorlatiasság elvét tüzték zászlójukra!" (Veszprémi 1988: 195.)

\section{Összegzés}

1948 előtt a gyermektanulmányozás, a gyermeklélektan új távlatokat nyitott a pedagógia értelmezésében, ezáltal a két terület, a két megközelítési mód elsőbbségi viszonya óhatatlanul felmerült. A két háború közötti időszakban is érzékelhető, hogy mindkét diszciplína normatív természetű, s a közpolitika részévé is ekképpen vált, ahogy Szegeden Várkonyi és az Intézetében dolgozó neveléspszichológus Boda István sorsa is mutatja. 1950-ben őket is nyugdíjazták és kizárták a tudományos életből, mint annyi, háború előtt a jobboldali eszmék, illetve a pszichológia felé tájékozódó, egymást kizáró világnézetű írástudót, mint Mérei Ferencet, Faragó Lászlót vagy Karácsony Sándort, Bognár Cecil Pált és Prohászka Lajost.

A háború után az egységes általános iskola létrejöttével megszűnt a polgári iskola, és a nyolcéves gimnáziumi képzés ideje megfeleződött, s velük együtt a tanárképzésük is. Pedagógusaik évtizedek alatt felépült identitása idővel elmállott az államszocialista neveléstudomány évtizedei alatt.

\section{IRODALOM}

Baróti D. (1988) Várkonyi, a professzor. In: Zakar A. (ed.) Várkonyi (Hildebrand) Dezső emlékkötet. Szeged, JATE Kiadó. 
Benda K. (1982, ed.) Magyarország történeti kronológiája, III. kötet. Budapest, Akadémiai Kiadó.

Fizel N. (2012) Az Állami Polgári Iskolai Tanárképző Főiskola és a Ferenc József Tudományegyetem együttmüködésének hatása Dolch Erzsébet életútjára. In: Kerekes B. \& GÁt Gy. (eds) V. Nyíregybázi Doktorandusz (PhD/DLA) Konferencia Elöadásainak közleménye. Nyíregyháza. Paper: 11.

Fizel N. (2013) A szegedi pedagógusképzés útkeresései a két világháború között Dolch Erzsébet életútjának tükrében. In: Fizel N. (ed.) Neveléstudományi tanulmányok a Szegedi Tudományegyetem múltjáról és jelenéröl. Szeged, Délvidék Kutató Központ. pp. 31-39.

Kiss N. (2016) A Waldorf-pedagógia alapelemeinek megjelenése az újszegedi Kerti Iskola oktatási/nevelési koncepciójában. In: Fizel N. (ed.) Gutta cavat lapidem. Hallgatói tanulmányok a neveléstörténet tárgyköréböl. Szeged, Délvidék Kutató Központ. pp. 9-25.

Makк F. \& Marjanucz L. (2011, ed.) A Szegedi Tudományegyetem és elödei története (1581-2011). Szeged, Szegedi Egyetemi Kiadó.

Németh A. \& Pukánszky B. (1997) Paradigmatikus irányzatok a magyar neveléstudomány fejlődéstörténetében. Magyar Pedagógia, Vol. 97. Nos 3-4. pp. 303-317.

Németh A. \& Pukánszky B. (1999) Magyar reformpedagógiai törekvések a XX. század első felében. Magyar Pedagógia, Vol. 99. No. 3. pp. 245-262.

Nóвік A. (2010) A polgár iskolai és a polgári iskolai tanárképzés 1928 előtt. In: KIss R. K. \& Vajda T. (eds) Az Állami Polgári Iskolai Tanárképzö Föiskola története (1928-1947). Szeged, Belvedere Meridionale. pp. 11-32.

Pitrik J. (1999, ed.) Szegedi Tanárképzö Föiskola: 1873-1998. Tanszéktörténet. Szeged, Hungária Kiadó.

Pukánszky B. (1999) Pedagógia és Pszichológia. In: Rácz B. (ed.) A Szegedi Tudományegyetem múltja és jelene, 1921-1998. Szeged, Officina. pp. 215-223.

PukÁnszky B. (2002) Reformpedagógiai Szegeden a két világháború között. In: NÉMETH A. (ed.) Reformpedagógia-történeti tanulmányok. Budapest, Osiris. pp. 101-120.

Rókusfalvy P. (1988) Várkonyi (Hildebrand) Dezső életműve. In: Zakar A. (ed.) Várkonyi (Hildebrand) Dezső emlékkötet. Szeged, JATE Kiadó. pp. 151-162.

Szabó D. É. (2016) Várkonyi Hildebrand Dezső fő gondolatai a Cselekvés iskolája című folyóirat tükrében. In: Fizel N. (ed.) Gutta cavat lapidem. Hallgatói tanulmányok a neveléstörténet tárgyköréböl. Szeged, Délvidék Kutatóközpont Alapítvány. pp. 26-39.

Szántó K. (1984) Várkonyi Hildebrand Dezső életútja és munkássága. Pedagógiai Szemle, Vol. 34. No. 12. pp. 1222-1232.

Szoкоцszкy Á. (2009, ed.) Lélektan 80 éves története a szegedi egyetemen 1929-2009. Szeged, Szegedi Egyetemi Kiadó.

T. Molnár G. (2010) A tanárképző főiskola szegedi megnyitása. In: KIss R. K. \& VAJDA T. (eds) Az Állami Polgári Tanárképzö Föiskola története (1928-1947). Szeged, Belvedere Meridionale. pp. 77-88.

VAJda T. (2010) Polgári iskolai tanárképzés a '30-as és '40-es években. In: Kiss R. K. \& Vajda T. (eds) Az Állami Polgári Tanárképzö Föiskola története (1928-1947). Szeged, Belvedere Meridionale. pp. 89-116.

Veszrprémi L. (1988) Várkonyi és a „Cselevés iskolája”. In: ZaKar A. (ed.) Várkonyi (Hildebrand) Dezső Emlékkötet. Szeged, JATE Kiadó. pp. 195-201.

Zakar A. (1988, ed.) Várkonyi (Hildebrand) Dezső emlékkötet. Szeged, JATE Kiadó. 


\section{MELLÉKLET}

\begin{tabular}{|c|c|c|}
\hline & \multicolumn{2}{|c|}{ Imre Sándor } \\
\hline $1926-1927-1$ & \multicolumn{2}{|c|}{$\begin{array}{l}\text { Neveléstörténet I. } \\
\text { Magyar pedagógusok. } \\
\text { Bevezetés az egyetemi életbe. }\end{array}$} \\
\hline $1926-1927-2$ & \multicolumn{2}{|c|}{$\begin{array}{c}\text { Neveléstörténet II. } \\
\text { A nevelői gondolkodás fejlődése Magyarországon. }\end{array}$} \\
\hline $1927-1928-1$ & \multicolumn{2}{|c|}{$\begin{array}{l}\text { Bevezetés a neveléstudományba. } \\
\text { A nevelés lélektani kérdései. } \\
\text { A középiskola szervezete. } \\
\text { Az egyetemi élet. }\end{array}$} \\
\hline $1927-1928-2$ & \multicolumn{2}{|c|}{$\begin{array}{l}\text { Oktatástan. } \\
\text { A serdülés kora. } \\
\text { Tanuló-típusok. }\end{array}$} \\
\hline $1928-1929-1$ & \multicolumn{2}{|c|}{$\begin{array}{l}\text { A neveléstörténet fökérdései. } \\
\text { A köznevelés szervezete. } \\
\text { Pedagógiai szeminárium. } \\
\text { A középiskolai oktatás módszere. } \\
\text { Bevezetés az egyetemi életbe. }\end{array}$} \\
\hline $1928-1929-2$ & \multicolumn{2}{|c|}{$\begin{array}{l}\text { A neveléstudomány fejlődése. } \\
\text { Teleki László gróf neveléstana (1796). } \\
\text { Szemináriumi gyakorlatok. } \\
\text { A középiskolai oktatás módszere II. }\end{array}$} \\
\hline 1929-1930-1 & \multicolumn{2}{|c|}{$\begin{array}{c}\text { A neveléselmélet alapvető kérdései. Az iskolai nevelő lélektana. } \\
\text { Szemináriumi gyakorlatok (a magyar nevelésügyi irodalom). } \\
\text { A középiskola belső élete. }\end{array}$} \\
\hline \multirow[t]{2}{*}{$1929-1930-2$} & \multicolumn{2}{|c|}{$\begin{array}{c}\text { Az oktatás elmélete. } \\
\text { Az iskolai növendék. } \\
\text { Szemináriumi gyakorlatok (a magyar nevelésügyi irodalom). } \\
\text { A középiskola belső élete. }\end{array}$} \\
\hline & Imre Sándor & Várkonyi Hildebrand \\
\hline 1930-1931-1 & $\begin{array}{l}\text { Neveléstörténet I. } \\
\text { Újító törekvések a nevelés terén. } \\
\text { Szemináriumi gyakorlatok. } \\
\text { Középiskolai kérdések. }\end{array}$ & $\begin{array}{l}\text { Karakterológiai vizsgálatok. } \\
\text { Bevezetés az alkalmazott lélektanba. } \\
\text { Pedagógiai-lélektani gyakorlatok. }\end{array}$ \\
\hline $1930-1931-2$ & $\begin{array}{l}\text { Az értelmi nevelés (Oktatástan). } \\
\text { A magyar közoktatásügy szervezete. } \\
\text { A nevelés szociológiája. } \\
\text { Középiskolai módszertan. }\end{array}$ & $\begin{array}{l}\text { Karakterológiai vizsgálatok II. } \\
\text { Didaktikai lélektani kérdések II. } \\
\text { Paedagogiai-lélektani gyakorlatok. }\end{array}$ \\
\hline
\end{tabular}




\begin{tabular}{|c|c|c|}
\hline $1931-1932-1$ & $\begin{array}{l}\text { Az erkölcsi nevelés. } \\
\text { Nemzedékek ellentéte a nevelésben. } \\
\text { Szemináriumi gyakorlatok. } \\
\text { Az iskola egészségügye. }\end{array}$ & $\begin{array}{l}\text { A pedagógiai lélektan jelen állása. } \\
\text { A gyermekkor lélektana. } \\
\text { Pedagógiai-lélektani gyakorlatok. }\end{array}$ \\
\hline $1931-1932-2$ & $\begin{array}{l}\text { Az értelmi nevelés (Oktatástan). } \\
\text { A magyar közoktatásügy szervezete. } \\
\text { A nevelés szociológiája. } \\
\text { Középiskolai módszertan. }\end{array}$ & $\begin{array}{l}\text { A gyermekkor lélektana II. } \\
\text { A pedagógiai-lélektan jelen állása II. } \\
\text { Szemináriumi gyakorlatok. }\end{array}$ \\
\hline $1932-1933-1$ & Nincs adat & Nincs adat \\
\hline $1932-1933-2$ & Nincs adat & Nincs adat \\
\hline 1933-1934-1 & $\begin{array}{l}\text { Neveléstani alapfogalmak. } \\
\text { A neveléstudomány mai állása. } \\
\text { Magyar neveléstörténeti kérdések. } \\
\text { Az iskolai oktatás anyaga. }\end{array}$ & $\begin{array}{l}\text { A karakterológia alapelvei. } \\
\text { Bevezetés a neveléslélektanba. } \\
\text { Pedagógiai-lélektani gyakorlatok. }\end{array}$ \\
\hline $1933-1934-2$ & $\begin{array}{l}\text { Neveléstani alapfogalmak II. } \\
\text { A családi nevelés. } \\
\text { Neveléselméleti kérdések. } \\
\text { Az iskolai élet rendje. }\end{array}$ & $\begin{array}{l}\text { Bevezetés a neveléslélektanba II. } \\
\text { A gyakorlati lélektan fókérdései. } \\
\text { Neveléslélektani és kísérleti lélektani } \\
\text { gyakorlatok. }\end{array}$ \\
\hline
\end{tabular}

\begin{tabular}{lc}
\hline & Várkonyi Hildebrand \\
\hline $1934-1935-1$ & A gyermekkor lélektana. \\
& Neveléslélektan. \\
& Lélektani gyakorlatok. \\
\hline $1934-1935-2$ & Pedagógiai alapfogalmak. \\
& Neveléstörténet II. \\
Gyermeklélektan. \\
Pedagógiai és lélektani gyakorlatok. \\
Neveléstörténet I. \\
Az iffúkor lélektana. \\
Bevezetés a neveléstudományba. \\
Pedagógiai-lélektani gyakorlatok.
\end{tabular}

$1935-1936-2$

A pedagógia története II.

Bevezetés a neveléstudományba II.

$\mathrm{A} z$ ifjúkor lélektana.

Pedagógiai-lélektani gyakorlatok.

1936-1937-1 Bevezetés a neveléstudományba III. (Módszertan.)

Gyermeklélektan.

Neveléstörténet (III.)

Pedagógiai-lélektani gyakorlatok.

1936-1937-2

A pedagógia története.

Bevezetés a neveléstudományba IV.

Gyermeklélektan.

Pedagógiai-lélektani gyakorlatok. 


\begin{tabular}{|c|c|}
\hline 1937-1938-1 & $\begin{array}{l}\text { Részletes módszertan. } \\
\text { Neveléstörténet. } \\
\text { Pedagógiai lélektan. } \\
\text { Pedagógiai gyakorlatok. }\end{array}$ \\
\hline 1937-1938-2 & $\begin{array}{c}\text { Az újkori nevelés története. } \\
\text { Neveléslélektan. } \\
\text { Részletes módszertan. } \\
\text { Pedagógiai-lélektani gyakorlatok. }\end{array}$ \\
\hline 1938-1939-1 & $\begin{array}{l}\text { A neveléstudomány rendszere I. } \\
\text { A gyermekkor lélektana. } \\
\text { Neveléstörténet a 19. sz.-ban. } \\
\text { Pedagógiai-lélektani gyakorlatok. }\end{array}$ \\
\hline 1938-1939-2 & $\begin{array}{l}\text { A neveléstudomány rendszere II. } \\
\text { A gyermekkor lélektana II. } \\
\text { Neveléstörténet a 19. században. }\end{array}$ \\
\hline 1939-1940-1 & $\begin{array}{l}\text { Az értelmi nevelés elmélete. } \\
\text { Az,új nevelés" mozgalma. } \\
\text { Az iffúkor lélektana. } \\
\text { Pedagógiai-lélektani gyakorlatok. }\end{array}$ \\
\hline 1939-1940-2 & $\begin{array}{c}\text { Az értelmi nevelés elmélete II. } \\
\text { A jelenkor föbb neveléstudományi irányai. } \\
\text { Az iffúkor lélektana II. } \\
\text { Pedagógiai-lélektani gyakorlatok. }\end{array}$ \\
\hline
\end{tabular}

A cikk a Creative Commons Attribution 4.0 International License (https://creativecommons.org/licenses/ by/4.0/) feltételei szerint publikált Open Access közlemény, melynek szellemében a cikk bármilyen médiumban szabadon felhasználható, megosztható és újraközölhető, feltéve, hogy az eredeti szerző és a közlés helye, illetve a CC License linkje és az esetlegesen végrehajtott módosítások feltüntetésre kerülnek. (SID_1) 